\title{
A NATUREZA DO FILÓSOFO
}

\author{
Emilia Maria Mendonça de Morais \\ sukuka@uol.com.br
}

RESUMO Considerando especialmente A República, diálogo em que a noção de phýsis está associada à de psykhé e à dimensão divina atribuída aos guardiões governantes, aborda-se a definição do filósofo, focalizando sobretudo o que Sócrates sugere ser a contrafação do exercício da filosofia. Se já não nos reconhecemos de nenhum modo próximos ao ideal contemplativo ou à theoría dialética, talvez nos seja mais acessível repensar a natureza do filósofo a partir do que nos é descrito como seu simulacro ou mesmo sua negação.

Palavras-chave Platão, República, filósofo, não-filósofo, natureza divina, theía moîra.

ABSTRACT The article analyses the definition of the philosopher, taking especially into account Plato's Republic, in which the notion of phýsis is associated with that of psykhé, and focusing mainly on what Socrates suggests to be the main counterfeit practice of philosophy. Since we no longer recognize ourselves at all in ideal contemplation or in dialectical theoria, a more accessible task to us may be to try to understand the nature of the philosopher from that which is described as being his simulacrum or even his negation.

Keywords Plato, Republic, philosopher, non philosopher, divine nature, theía moîra.

* Profa. aposentada do Depto. de Filosofia da UFPB. Recebido em 6/5/2010 e aprovado em 2/7/2010.

KRITERION, Belo Horizonte, nº 122, Dez./2010, p. 473-488. 
Se na tradição pré-socrática a concepção de phýsis aparece tanto associada à superação do mito e da intervenção divina, quanto à afirmação de um princípio material ou imanente ao cosmos, quando transposta para $A$ República e à definição do filósofo, essa noção ressurgirá vinculada à $p s y k h \underline{\text { é }}$. Apesar da concepção tripartite da alma, apresentada por Sócrates no livro IV do diálogo, incluir o desejo e as carências fisiológicas (em marcante diferença com a oposição dicotômica entre corpo e alma do Fédon), a natureza do filósofo não se subordina a nada que seja orgânico ou fisiológico. Desprendida da materialidade, conforma-se ao pensamento e permanece atada ao divino cujo apelo integra verdade e justiça. Divina seria, então, a própria filosofia: o maior benefício que os deuses concederam à raça dos mortais, segundo o Timeu; assim como o método que a define, a dialética, fora um presente dos deuses aos humanos, segundo o Filebo ${ }^{1}$. Falar dessa natureza do filósofo, por conseguinte, pressupõe abordar a natureza mesma filosofia. No caso de um filósofo grego antigo e, mais particularmente, de Platão, filosofia e vida estão tão imbricadas, sobretudo se levarmos em conta o registro do testemunho socrático, que se torna quase impossível distingui-las.

A primeira imagem delineada do filósofo nos escritos de Platão é a do próprio personagem Sócrates, visando sempre a uma sabedoria que se descola do solo do prestígio público, seja pelo modo despojado como vive, seja pela direção à qual orienta seu pensamento, construindo, assim, um discurso desafinado do que se costuma ouvir no âmbito da pólis ${ }^{2}$. Aquele que se consagra à filosofia não apenas vive à parte das inquietações que movem seus concidadãos, mas dirige-se aos mesmos por meio de interpelações que sempre lhes soam tão singulares quanto excêntricas. Desde os primeiros passos da Apologia, o personagem do filósofo chama a atenção para a sua fala estranha aos tribunais ${ }^{3}$, tal como um idioleto, antes mesmo de discorrer sobre a sua vida desvinculada das ocupações políticas e dos interesses particulares - que a prática política se atenha ao particular e não à justiça, esse é o distintivo da pólis cujos governantes mantém-se distanciados do exercício da filosofia. Ressonâncias desse estranhamento reencontramos no Górgias e no Teeteto. No diálogo com Polo, consagrado ao exame da oratória, Sócrates relembra que provocou risos por sua inabilidade quando fora convocado a exercer na Assembléia as funções da pritania. Para Cálicles, o mais inflamado porta-voz

2 Que Sócrates foi o mais sábio de seu tempo é o que podemos ler na conclusão do Fédon (118c); também foi aquele a quem menos caberia qualquer acusação de impiedade na Carta VII (325 b-c).

3 Apologia, $17 \mathrm{~d}$. 
da retórica sofista, por toda a sua atenção à filosofia e inapetência para lidar com os assuntos práticos da pólis, Sócrates findaria por habitar uma casa vazia ${ }^{4}$. No Teeteto, Sócrates retoma esse tema da excentricidade dos mais sábios: evoca a Teodoro a anedota sobre Tales, tão desligado do mais imediato que, ao caminhar, fora incapaz de enxergar um poço a sua frente; indiretamente, refere-se também a si mesmo quando discorre sobre a inaptidão prática dos filósofos, sempre provocando a chacota, ora de incultas jovens trácias, ora dos seus mais ou menos próximos concidadãos ${ }^{5}$.

Na encenação dos diálogos, a lição do colóquio dramático do Fédon: viver e refletir à margem do burburinho da agorá decorre da atribuição primeira e permanente de todos aqueles que se consagram à filosofia; mirar para além do visível, atar a alma ao invisível e, assim, sondar o eterno e o divino. Durante o seu processo, Sócrates reconhecera seus vínculos diretos com Apolo, o deus que, por meio da resposta à consulta de Querofonte ao oráculo de Delfos, levara-o a fazer da filosofia um exercício aberto e público; desde então, o exame de si mesmo passou a ter seu lado reverso e complementar: o exame dos pretensos sábios da pólis ${ }^{6}$. Esses mesmos vínculos são reafirmados no Fédon pois o filósofo, identificando a filosofia à forma mais elevada de música, teria até mesmo composto uma melodia para o hino ao deus oracular, ao qual, rememorando o canto divinatório dos cisnes na iminência da morte, se reconhecera consagrado ${ }^{7}$.

Em paralelo ao deus explicitamente designado, evoca o signo do divino (daimónion), seja através da voz (phonée), que guia o filósofo porquanto o retém, seja através do Eros mediador que, a partir do desejo de um só corpo, rege a sua progressiva ascensão do sensível até a contemplação da beleza como Forma inteligível $^{8}$. No Banquete, o discurso atribuído a Alcebíades associa o próprio Sócrates ao percurso ascético que Diotima expusera para atar o elo amoroso ao elã extático proporcionado por $\operatorname{Eros}^{9}$. No relato mítico do Fedro, o filósofo é representado como um humano possuído pelo divino e, no Timeu, a intelecção da qual participa os deuses (noû dè theoús) é também atribuída a alguns poucos dentre os humanos ${ }^{10}$. Há um pressuposto comum e recorrente que se estende desde o personagem Sócrates até as demais representações do

\footnotetext{
Cfr. Górgias, 473e-474a e 486c.

Cfr. Teeteto, $174 \mathrm{a}$ e segs.

Cfr. Apologia, 20 e e segs. e $28 \mathrm{e}$.

Cfr. Fédon, 60d e segs; e 84 e e segs.

Cfr.Apologia, 31d e Banquete, 202d e segs.

9 Cfr. Banquete, 214 e e segs.

10 Cfr. Fedro, 249d e Timeu, 51e.
} 
filósofo, tanto pelo relato mítico quanto pelo contorno do lógos: é sempre a partir da crítica ao predomínio da política e da educação peculiares à sofística que se estrutura a explicação do não reconhecimento do caráter filosófico pela larga maioria dos seus concidadãos.

O Sofista, diálogo tardio, ainda pode ser lembrado como um dos vários exemplos de que, para Platão, numa vida pautada pela filosofia não se firmariam rupturas nem sequer distâncias instransponíveis entre a práxis e a theoría orientada à esfera do supra-sensível. Reconstruindo os parâmetros teóricos da hipótese das Formas inteligíveis, o diálogo começa com o elogio do filósofo e termina com o menosprezo do próprio sofista. Em seu prólogo, Teodoro afirma ser o Estrangeiro de Eléia um filósofo, não um deus, mas um ser divino, como seriam todos os filósofos. Sócrates mostra-se de acordo mas advertelhe que o gênero divino não é fácil de definir por revestir-se de múltiplas aparências entre os humanos; embora os filósofos enxerguem as multidões e a vida dos homens das alturas em que se mantêm, podem ser confundidos com políticos ou até mesmos sofistas ${ }^{11}$. Depois da longa discussão, da reconstrução da questão do ser a partir dos gêneros supremos e da noção de alteridade ontológica, o diálogo se encerra com a sentença que reduz a sofística a uma mera arte imitativa que, ao fomentar contradições no terreno das opiniões, apenas produz simulacros e ilusões; por isso seus porta-vozes pertenceriam a uma raça apenas humana, de nenhum modo divina ${ }^{12}$.

Platão aborda tanto a natureza do filósofo quanto a atividade filosófica por proposições afirmativas, mas também por justaposições que se constroem através de negativas - ora adverte-nos sobre o que o filósofo e a filosofia não podem deixar de ser, ora sobre o que não podem ser. No alvo das negações, invariavelmente, estão os sofistas e a sofística. É assim no Protágoras, no Górgias, no Fedro, na República, no Teeteto e no próprio Sofista. A distinção talvez mais marcante e recorrente seja justo a que acabamos de ressaltar: a vida e o pensar do filósofo concernem ao divino e a prática dos sofistas diz respeito apenas ao humano, ou melhor, ao mundano.

Vejamos alguns dos termos pelos quais o caráter do filósofo é associado ao divino. Na Apologia, ao enfatizar sobre o que significa fazer filosofia, Sócrates reconhece que podia ser prazeroso aos jovens ouvi-lo, quando desnudava a pretensão daqueles que se pretendiam sábios sem, efetivamente, sê-lo; porém sobre a sua prática interrogatória, o seu exercício público e peculiar de pensar, não vacila em admitir: 
"Para mim, repito, é alguma coisa que o deus me prescreveu fazer por intermédio dos oráculos, dos sonhos e por todos os meios enfim de que se vale uma concessão divina (theía moîra) para prescrever a um homem a tarefa que lhe é própria"13.

A expressão theía moîra, designativa da atividade filosófica, também presente na Carta VII, pode ser associada, nos termos do Ion, a uma potência, theía dýnamis ${ }^{14}$. No relato mítico do Protágoras aparece para designar o que, a partir do dom de Prometeu, os seres humanos alcançaram partilhar com o divino: a capacidade criadora e inventiva das tékhnai ${ }^{15}$. Na conclusão do Mênon, Sócrates sustenta a seu interlocutor: por não advir da natureza nem ser coisa possível de ser ensinada, a virtude surge neste mundo por meio da theía moîra. No Mênon, são chamados também de divinos os homens que, mesmo sem terem a inteligência ou a ciência da virtude, tornam-se capazes de se conduzirem corretamente (áxion toǘtous theíous kaleîn toùs ándras); se existissem políticos aptos a ensinar a virtude, esses seriam, entre os vivos, libertos das sombras errantes como, segundo Homero, teria sido Tirésias no Hades $^{16}$.

Se, no livro VII d'A República (540 b-c), Sócrates prescreveu o culto aos governantes exemplares mortos tal como se fossem daímones, em outros diálogos refere-se aos homens divinos em vida. São várias as passagens que, mais ou menos diretamente, aludem a homens sábios e superiores, como se pertencessem a uma estirpe celestial. No Crátilo, o filósofo rememora os homens da raça de ouro dos versos de Hesíodo:

"Depois que a terra fez desaparecer esta raça eles são, pela vontade de Zeus poderoso bons gênios ctônicos, guardiões divinos dos mortais" (phýlakes thnetôn anthrópon $)^{17}$.

Assim como n'A República, a condição demoníaca ou divina seria um atributo concedido aos mortos. Porém, logo em seguida, continuando a discussão com Hermógenes sobre a correção natural dos nomes, Sócrates acrescenta uma outra dimensão à crença de Hesíodo e àquela que transmitira a Gláucon:

"Ele decerto tem razão, ele e tantos outros poetas, ao dizer que, quando um homem de bem morre, detém da fortuna uma alta reputação e se torna

13 Apologia, 33c; trad. a partir de L. Brisson, Paris, Flammarion.

14 Carta VII, 326: theías môiras; Ion, 533d e 534c

15 Protágoras, 322a: theías metéskhe moîras.

16 Mênon, 99c e 100b; cfr. em 99d, a expressão "theîos anér" . E cfr. Homero, Odisséia, X, 494-495.

17 Trad. a partir de C. Dalimier, P. Mazon e M. C. N. Lafer; cfr. Crátilo, 397e-398a e República, 469a. Cfr. Hesíodo, Os trabalhos e os dias, versos 121-123 (toì mèn daímonés eisi Diòs megálou dia boulàs). 
potência divina, segundo a denominação que lhe cabe por sua sabedoria. É assim que eu também estabeleci o nome daémon: afirmo que todo homem bom, tem qualquer coisa de divino (daimónion eînai), que ele esteja morto ou vivo, e que é correto chamá-lo daímon"18.

No livro II d'A República, retomando as hipóteses sofísticas de Trasímaco e discorrendo sobre as vantagens da vida injusta, Adimanto sustenta que ninguém é justo voluntariamente, a menos que, por uma natureza divina (theía phýsei, 366c), seja preservado de cometer injustiças. O que, afinal, aproximaria a natureza do filósofo dessa esfera do divino? Do ponto de vista teórico, lembremos da definição do sábio que Sócrates nos propõe no livro $\mathrm{V}$ do diálogo. Ao tratar da ciência, porque quem se consagra à filosofia buscando tudo saber é também um philomathés ${ }^{19}$, Sócrates visa, antes de tudo, focalizar a disjunção entre os domínios do conhecimento e o da opinião, correspondentes, respectivamente, ao inteligível e ao sensível. A noção de eídos, aliada à compreensão do que seria o filósofo, ou melhor, os reis filósofos (oi philósophoi basileúsósin, 473c), começa a ser mais claramente esboçada em 476c onde, evocando o belo em si, o filósofo introduzirá a noção de conhecimento, justapondo por uma divisão tripartite: a pólis, composta de artesãos, guardiões guerreiros e guardiões governantes, à psykhé (desejante, impetosa e pensante) e, por fim, às virtudes (temperança, coragem e prudência/ sabedoria) que culminam na justiça; por essa via, associa o Ser à ciência, o não-ser à ignorância; como intermediários (metaxý), no plano da ontologia, designa toda a multiplicidade das aparências e, no plano do conhecimento, a opinião. Sábio seria aquele afeito a investigar e apreender a unidade do Ser através da multiplicidade infinita do sensível; sofista, aquele enredado entre o ser e não-ser, dominado por todas as fantasias perceptivas e cujos discursos, por isso mesmo, nunca escapariam ao âmbito do opinativo ${ }^{20}$. Muitos males adviriam para a pólis dessa cegueira sofística e a muitos sofrimentos estariam sujeitos os verdadeiros filósofos ${ }^{21}$.

No livro VI, Sócrates alerta para os riscos maiores dos desvios pedagógicos de que podem ser vítimas aqueles que são dotados de uma natureza filosófica (philosóphoy phýsin), quando se deixam arrebatar pelos discursos dos

18 Crátilo, 398b-c (grifo nosso); trad. a partir de C. Dalimier, Paris, Flammarion.

19 Cfr. República, 475c; 376c e 581b.

20 República, 472e-480a. Nessa proposição triádica simplificada, não temos ainda a mediação atenuante da alêthès dóxa, diversa da pseudès dóxa; no livro IX, Sócrates relacionará opinião verdadeira e ciência, hipótese também aventada no Mênon, 98-b-c, no Teeteto, 187a e segs., 201c e segs., e na conclusão do Filebo 66b-c.

21 Cfr. República, 488a; pode-se aproximar o sábio expulso da pólis ao modelo do justo perfeito, sugerido por Gláucon, 361b-362a . 
sofistas. Em tais casos, só o auxílio advindo pela intervenção divina (tis autêi boethésas theôn týkhe) poderia preservar os jovens seduzidos e prisioneiros dos mais nefastos malefícios ${ }^{22}$. Quando habitantes das sociedades regidas pelas ilusões sofistas, esses caracteres dotados para a filosofia poderiam ter a sua índole original desvirtuada ao ponto de se tornarem as mais perversas caricaturas dos verdadeiros filósofos. Se o cuidado pedagógico, na sociedade modelar, resguardaria os caracteres filosóficos da degeneração, no âmbito das formações sociais onde os jovens são guiados pelas imagens sombrias do real, apenas seres humanos excepcionais são preservados de toda corrupção, pois a sua natureza se afirmaria pelo suporte da intervenção divina; sem a intercessão auxiliar de um dos deuses, não se manteria incorrupta (cf. Rep. 492a5). Alguns poucos passos adiante o filósofo sentenciara:

"Não há, nunca houve e nem haverá um caráter formado na virtude contra as lições que a multidão subministra; falo, meu amigo, de um caráter humano (anthrópeion). Quanto ao caráter que é divino (theîon), segundo o provérbio, deixemos de mencioná-lo. (...) Se, em tais governos, existir um que se salve e se torne o que deve ser, podes afirmar sem medo de errar que essa salvação se deve a uma intervenção divina (theô̂ moîran)" "23.

Em seguida, insistindo ainda e prevenindo Adimanto sobre as ameaças de corrupção que sofrem nesse meio corrompido aqueles poucos dotados de uma verdadeira inclinação para a filosofia, Sócrates alude a seu próprio signo divino (daimónion semeîon) ${ }^{24}$; decididamente, nenhum dos atuais governos, lamenta Sócrates, mostra-se digno de ser conduzido por governantes afeitos à filosofia, a não ser se, por um feliz acaso, lhe sobrevenha alguma inspiração divina (theías epipnoías) ${ }^{25}$. Enquanto esse acaso não ocorre, o filósofo mantém-se inalterável em seus desígnios, mesmo quando se defronta com uma multidão ensandecida.

No livro VI, Sócrates vale-se ainda de uma metáfora, a de uma nave desgovernada, para falar do filósofo, estranho e inútil aos concidadãos que não o reconhecem. Se numa sociedade de justos os homens brigariam entre si a fim de se manterem distantes do governo, os marinheiros dessa nave, imagem da pólis subordinada às seduções do poder, permaneceriam em constantes sedições; ávidos pelas posições de comando e disputando o leme

22 República 492a;

23 República 492e-493a; trad. a partir de A. L. de Almeida Prado e J. Guinsburg.

24 República, 496c.

25 República, 499c; e cfr. 497a e segs. 
da embarcação, findam por expulsar o timoneiro do seu posto, o único ciente das regras e exigências da arte náutica ${ }^{26}$.

No turbilhão da pólis mal governada ou acéfala, o filósofo se retrai para contemplar o que é efetivamente real (pròs tô̂s oûsi), o que é ordenado e permanece sempre no mesmo estado (tétagméta átta kaì kata tauta aeì ékhonta ${ }^{27}$. "Assim, convivendo com o divino e ordenado (teió kai kosmiói) o filósofo torna a si mesmo divino e harmonioso, o quanto é possível a um ser humano (theîos eis tò dunatón anthrópoi gígnetai). Reportando-se apenas a esse modelo divino (tôi theíoi paradeígmati), o filósofo transforma-se ao ponto de, neste mundo, divisar o que é por natureza justo, belo e moderado (tò phúsei díkaion kaì kalón kaì sôphron) ${ }^{28}$. Valendo-se de Sócrates como mediador, Platão parece ir longe demais porém, se tudo é uma questão de medida a ser seguida, em se tratando da filosofia, não há meio termo ou cânone de meia medida, não há comedimento algum para firmar o paradigma da excelência humana; qualquer medida que se afaste, por pouco que seja do divino não é uma boa medida: de nenhum modo o imperfeito (inacabado) (atelès) pode ser medida de coisa alguma ${ }^{29}$.

Através do relato alegórico, na abertura do livro VII, Sócrates não nos ajuda muito a compreender por que há destinos humanos excepcionais que se cumprem em sentido contrário a todas as mais ordinárias experiências e previsões; é o pronome indefinido $t i s^{30}$ que exprime o que impulsiona o homem, prisioneiro no interior da caverna, a desamarrar seus grilhões, revirar o seu corpo e a direção do seu olhar; para suportar a dor de um percurso estranho e individual (isolando-o da mais larga maioria dos habitantes da caverna) e a seguir passo a passo, numa conversão progressiva, até alcançar o espaço exterior, tornando-se, enfim, capaz de contemplar as Formas inteligíveis e o princípio não hipotético do Bem. ${ }^{31}$

Fora desse longo e difícil percurso da filosofia, resta quase sempre o arremedo pedagógico da pólis democrática ou o pesadelo da tirania. No livro VIII, ao explicar a tirania como uma decorrência da democracia, Sócrates sustenta que essas duas formas mais corrompidas de governo poderiam ser compreendidas e até mesmo justificadas pelas crenças e práticas políticas da

26 República, 347d-e e 480a e segs.

27 República, 500 b-c.

28 República, 500 c-d; 501 b.

29 República, 504c: métron tôn toioúton apoleîton kaì hotioûn toû óntos ou pánu metríos gígnetai: atelès gàr oudèn oudenòs métron. A questão da medida com relação aos prazeres e ao bem na vida humana, será retomada, especialmente, nos passos conclusivos do Filebo: $64 \mathrm{e}$ e segs.

30 República, 514c

31 Cfr. República, 516a-517c. 
sofística - hipóteses antecipadas tanto no livro I quanto em diálogos anteriores. Consequentemente, enquanto face avessa do filósofo, Platão identifica o sofista, tanto ao arauto da democracia quanto ao porta-voz da mais desmesurada tirania. No primeiro caso, põe em foco o mestre de Abdera e os pressupostos relativistas do ánthropos métron ${ }^{32}$. Para ilustrar o segundo, vale-se, sobretudo, de Cálicles, no Górgias, mas também de Trasímaco n’A República. Em ambos, o apego às honras sociais, a atração pelo poder; no caso da tirania, o fascínio pela força e pelo espetáculo do social, diferenças e nuances à parte, exacerba a tentação desmedida pelo poder absoluto e arbitrário. As possíveis distinções entre um Trasímaco mais fatalista ou, por assim dizer, "positivista" com relação às vantagens inerentes ao exercício do comando, e um Cálicles amoralista que, do ponto de visa da moral e da lei, antecipa as transvalorações nietzscheanas, tem contornos difusos. Nesse jogo de prestígio e força visando à sedução e ao domínio do grande animal social (thrémmatos megálou kaì iskhyroy, Rep. 493a), o sofista não passa de um domador fragilizado, propenso a ser devorado pelo monstro que alimenta.

Se todos os discursos podem ser validados, por que o discurso do mais forte haveria de ser negado? Se os múltiplos logói podem exprimir e justificar qualquer percepção fragmentada, qualquer experiência ou proposição política dilacerante para a pólis, o fundamento do pensamento e da vida do filósofo têm de se firmar alhures. Poderíamos continuar parafraseando Platão para nos estendermos sobre essa natureza humana que se torna apta a mirar a região do inteligível, segundo a fábula e o lógos da República; sobre sua vida contemplativa, desenraizada da caverna, sobre suas palavras construtoras de hipóteses acerca das Formas supra-sensíveis até firmar-se no princípio não hipotético do Bem em si, para além do ser ou da essência em dignidade e potência (tês ousías presbeíai kaì dunámei), reinando sobre tudo o que é em si e por si, autò kath' hautò ${ }^{33}$. Poderíamos ainda nos estender sobre a reta segmentada, os quatro planos correlatos do ser e do conhecer e tudo o que lhe diz respeito: as sombras, as nossas fantasias e crenças, os objetos do nosso mundo, as entidades e ciências matemáticas, as Formas e a dialética, as aparências e a essência, as relações entre o múltiplo percebido e o uno pensado, as alusões à educação matemática e à iniciação à dialética, necessárias à formação do

32 Cfr. Protágoras, 320d-323c; Teeteto, 166a-168c.

33 República, 509b. Trata-se, afinal, de compreender tanto a essência do Bem quanto a própria ordenação da pólis . Desde os primeiros passos do livro Il do diálogo, Glaucon interrogara Sócrates sobre o que seria a justiça autò kath' hautò (358d). 
filósofo; enfim mais e mais discorrer sobre o programa pedagógico inscrito no livro VII do diálogo.

Preferimos, todavia, parar por aqui. Afinal, apostando que, ainda hoje, é possível, e talvez até mesmo desejável, levar Platão a sério, para além das paráfrases dos diálogos, o quanto seria possível vislumbrar da diánoia que mal traduzimos por discurso ou pensamento, ou da nóesis, que mal traduzimos por intelecto ou por intuição intelectual? Quão distante já estamos de um percurso dialético que visa costurar o tecido por demais triturado do real e do conhecimento? Não nos formamos numa pólis paradigmática, não estamos dotados da theía phýsei nem da theía moîra, sequer conseguimos vislumbrar signos do divino em nossas vidas. Diante de todas as perversões e desvarios, em nós mesmos e fora de nós, em tudo que nos cerca, só nos restaria a nostalgia de uma sabedoria irremediavelmente perdida?

Platão nos legou algumas fábulas acerca da condição humana. Na abertura do livro VII d'A República, através da alegoria da caverna, somos levados a compreender por que, sem a ascese filosófica ou a iniciação dialética, sem o $t i s^{34}$ indefinido que impulsiona a conversão para a nossa libertação, permaneceríamos prisioneiros de um espaço subterrâneo onde, sob uma precária luz, apenas observamos sombras de marionetes, manipuladas por estranhos que desconhecemos. Conforme o mito da parelha alada do Fedro, seríamos como um cocheiro debatendo-se para manter o controle e bem conduzir uma atrelagem alada, embora os dois cavalos que a movem tendam para direções opostas; somente um custoso aprendizado oriundo da loucura erótica, outorgada pelos deuses, possibilitar-nos-ia seguir os rumos do cavalo branco ou da ascensão da alma até a região do hyperouranós ${ }^{35}$. No primeiro livro das Leis, temos uma outra imagem de prisão; ali, seríamos nós mesmos as marionetes, joguetes fabricados pelos deuses; estranhos artefatos, porque os fios das afecções que nos prenderiam, comandando nossos movimentos, não seriam fios de suspensão às esferas celestes, mas fios com trações diversas: o mais maleável, símbolo da razão (logismós), seria o fio de ouro, os demais puxando-nos para outras direções seriam mais pesados ou mais duros como o ferro ou outros metais. O fio da razão seria o mais flexível porque não se sujeitaria à coação; embora possa ser transmutado em lâminas, o ouro não é suscetível à corrosão; assim também o caráter do verdadeiro filósofo ${ }^{36}$. 
Platão tem sido considerado um arquiteto de projetos utópicos e atópicos; suas imagens fabulosas mostram-nos, todavia, o quanto ele estava atento à dificuldade de soltarmos as nossas mais resistentes amarras. N'A República só inicia o discurso sobre o projeto do estado modelo depois que Sócrates se confessa impotente diante dos argumentos de Gláucon e Adimanto. Se nos livros intermediárias do diálogo temos a aposta em uma sociedade pedagógica e em uma dialética ascendente para formar os seus governantes, a partir do livro VIII, o foco se direciona às sociedades sujeitas ao declínio, marcadas pelo signo da corrupção; sobretudo os dois últimos livros do diálogo compõem um drama tangenciando o trágico em torno da degradação tanto da pólis, através da tirania, quanto da alma por meio da poesia desconectada das representações do divino regidas pelo $\mathrm{Bem}^{37}$. Ainda assim, diante da impossibilidade histórica de uma pólis filosófica, Sócrates nos convida a edificarmos a nossa pólis interior e o mito de Er, na conclusão do diálogo, é também uma constatação de nossa liberdade primordial, apesar do mal uso que dela fazemos; afinal, nós mesmos seríamos levados a escolher nossas próprias vidas ${ }^{38}$.

Se o grande e forte animal é a metáfora que melhor traduz o social é porque nossa alma mesma é a imagem de um animal policéfalo (uma espécie de amálgama de Quimera, Cila e Cérbero), com cabeça de múltiplos animais selvagens ou domésticos, à qual se junta a forma de um grande leão e de um pequeno homem. Esse estranho e múltiplo composto que, em sua aparência externa, parece-nos uno seria o que chamamos ánthropos - a pequena parte da alma, o homem interior, corresponderia à porção do divino (tôi theío $i^{39}$ ) em nós. Adestrar todos os nossos animais internos e indômitos, cuidar da diminuta forma humana que eles ameaçam ou subjugam, é ao que Sócrates nos chama: trata-se, portanto, de construir nossa pólis interior. O sábio que nunca é chamado para ordenar a pólis em que vive, ordena a sua própria alma como uma pólis, outorgando-lhe uma constituição interna visando ao governo racional de si mesmo (autôi politeían ${ }^{40}$ ); assim, a sua alma consagra-se à imitação do divino. Se o divino socorre o humano, nem que seja apenas por contenção para preservá-lo de praticar ações que o desviariam de sua natureza original, é também porque o humano se volta para o divino, em mútua cumplicidade; ultrapassando as distinções sofistas e os conflitos entre physei

37 Não podemos nos esquecer que toda a crítica à poesia desenvolvida no livro X d' $A$ República, 595a608d, é precedida pela advertência inscrita no livro II do diálogo:do divino só se poderia dizer o bem e o verdadeiro, (379b e segs. e 382e)

38 República, 617d; sobre a pólis interior, cfr. 591d-592b e 608a-b.

39 República, 589d e cfr. 589 a-b.

40 República, 591e. 
e nomôi, a vida do justo torna-se pautada pela conformidade com o divino (homoiósis theoi), apelo d' A República reposto na denominada digressão no Teeteto ${ }^{41}$.

Talvez seja menos difícil abordar, não a nóesis ou a dialética das Formas inteligíveis, mas o que, efetivamente, faz parte deste nosso mundo concreto e visível; do que está muito mais próximo de nossas experiências vividas e reflexivas, mundo abandonado pelos deuses, deuses que nós mesmos abandonamos. No espaço acadêmico, distante da pólis paradigmática, em um mundo em que o trabalho e a ciência encontram-se fragmentados e não apenas divididos, estamos mais afeitos a uma perspectiva própria ao relativismo, exercitando contradições, antilogias ou aporias sem mais pretensões a quaisquer totalizações teóricas ou a grandes sínteses discursivas. Nesse espaço nos encontramos porque, de algum modo, somos afeitos à filosofia, porém já não somos philosóphos à moda antiga, talvez menos ainda no sentido socráticoplatônico, pois não mais buscamos a sabedoria das iniciações ascéticas ou dos testemunhos exemplares da justiça. Em nossas democracias capengas, de fato, oligarquias eletivas onde representantes e governantes chegam a seus postos pelo decisivo impulso das retóricas e imagens publicitárias, vivemos muito próximos da sofística. Se já não somos filósofos, consideramo-nos, no mínimo, phílos da filosofia. E poderíamos, voltar à República para pensar, menos a natureza do filósofo, cujo modelo já está tão afastado de nós, e mais para pensar o que corrompe essa natureza. Por esse caminho, talvez, seja-nos possível chegar mais perto de Platão ou fazer Platão chegar mais perto de nós. Se não mais perto, ao menos não tão distante, embora sem ilusões de reencontros tardios e impossíveis com o passado.

No meio social em que vivemos, próximos da sofística ou até mesmo do Leviatã hobbesiano, o social também identificado a um monstro animal, apenas uma inspiração divina (theía epipnóia ${ }^{42}$ ), admitindo a hipótese platônica, poderia tornar filósofos os que detêm o poder. Todavia como seria possível essa irrupção da norma do divino no seio de uma sociedade corrompida? Por que nos corrompemos, sempre desejosos e insatisfeitos, tornando-nos mais ou menos próximos de um crivo repleto de furos ao qual Sócrates alude em seu diálogo com Cálicles no Górgias ${ }^{43}$ ? O que podemos fazer de nossa liberdade? 
Com poderia, então, diante de todas as impossibilidades históricas e políticas, um ser humano tornar-se esse artesão de si mesmo no interior da pólis imperfeita? Essa é uma questão de ressonâncias míticas. Tal como Dédalo, construindo suas próprias asas, Sócrates, argumentador fixado nos paradigmas das tékhnai, sábio artesão de si mesmo, construiu asas simbólicas, contemplativas, que lhe permitiram manter-se atento ao lógos e ao divino embora deambulando e dialogando na agorá, âmago da pólis. No entanto, lições do Protágoras, do Górgias e do Mênon, a virtude não seria objeto de ensino, não como as demais artes ou ciências. Sócrates relembrava sempre aos seus interlocutores que homens de talento político, como Péricles ou Temístocles, não souberam transmiti-lo a seus filhos ou concidadãos ${ }^{44}$. A virtude, em suma, depende da atenção ao Justo, pelo esforço de cada um. O mito da atrelagem alada no Fedro quase nada prescreve sobre como melhor ou mais rápido domar e dirigir o cavalo rebelde para a ascensão da alma às esferas celestiais ${ }^{45}$. Dédalo doara a Teseu tão somente um fio; o sábio apenas lançava as suas perguntas. Ambos impulsionaram e apelaram à anámnesis mas o percurso, sempre solitário, haveria de ser do próprio Teseu, assim como de cada interlocutor do filósofo. Tanto quanto a virtude, o vôo da alma também não se ensina. Ícaro, por não ter construído suas próprias asas, não conseguiu apreender as lições de Dédalo e submergiu no mar $^{46}$.

O que tornaria possível, neste mundo corrompido, um ser humano escapar de viver contaminado por ambições de prestígio e não sucumbir a desejos desmesurados? Podemos tentar responder essa questão a partir de onde nos situamos: não nas instituições governamentais de nossas sociedades, mas no espaço acadêmico, na república das letras. Recuando, ao início do livro II d' $A$ República e às questões de Gláucon a Sócrates, relativas à justiça, podemos transpô-las para pensar o modo como exercitamos a filosofia. Interroguemonos, então, sobre que espécie de bem é, para nós, pesquisar ou lecionar filosofia:

a) se é um bem que prezamos apenas por si mesmo;

b) se é um bem que apreciamos por si mesmo mas também por seus benefícios exteriores;

44 Cfr. Protágoras, 319 e segs.; Górgias, 515b e segs; Mênon, 93b e segs.

45 Cfr. Fedro, 246a- 257c.

46 Cfr.. MORAIS, E. M. de e SOARES, M. L. "Divagações platônicas em torno do mito de Dédalo," in Actas del XVVII Simpósio Nacional de Estúdios Clásicos: Memória y olvido en el mundo antíguo, Bahia Blanca, Universidad Nacional del Sur, 2002. 
c) se o exercício do filosofar seria aquela terceira espécie de bens árduos de praticar que valorizamos tão somente pela utilidade dos seus resultados ou por suas vantagens materiais ${ }^{47}$.

Se não praticamos o amor da sabedoria apenas por si mesma (afinal, somos pagos para pesquisar e lecionar e dependemos desse ofício para sobreviver), tentar pensar por nós mesmos não deixa de nos comprazer; sendo assim, não exercitamos a filosofia, nem como uma espécie de missão divina, nem apenas como uma tarefa árdua da qual extraímos apenas recompensas que lhe são exteriores; consequentemente, se não estamos no primeiro nem no terceiro caso, só podemos nos situar no segundo, ou seja, prezamos a atividade filosófica por si mesma e pelas compensações exteriores que ela nos proporciona.

Deixemos, por enquanto, esse paralelo em suspenso e rememoremos alguns passos dos os livros VIII, onde Sócrates relaciona os caracteres humanos às formas de governo. Seriam cinco os tipos humanos: o aristocrata correspondente ao governo bom e justo, e, além desse tipo ideal, mais outros quatro, correlatos às formas degeneradas de governo - a saber: o homem timocrático, o oligárquico, o democrático e o tirânico ${ }^{48}$. Esses tipos corrompidos, concernentes diretamente à pólis, não seria tarefa fácil transpôlos para a república das letras. Mas, avançando para o livro IX, vemos que Platão reduz os cinco caracteres humanos a apenas três aos quais se vinculam três espécies de prazeres: em primeiro lugar, está o aristocrata, o homem real da pólis e, antes de tudo, rei de si mesmo (basilikótaton kaì basileuonta autoy ${ }^{49}$ ); assim, em ordem decrescente, temos o philosophón, ao qual se segue o philónikon e, por último, o philokerdés ${ }^{50}$; sendo o primeiro o amigo da sabedoria, o segundo poderia ser considerado o amigo do triunfo, do êxito ou da honra; e o terceiro o amigo do ganho ou da ganância.

Se não somos filósofos, seja porque já não somos guiados por gênios ou deuses, seja porque não temos chances de habitar uma pólis paradigmática (afinal, a República propõe-nos apenas um modelo discursivo ${ }^{51}$ ), não podemos ser amigos da sabedoria, ao menos no rigoroso sentido socrático-platônico que exige a plena atenção ao saber desdobrando-se em inequívoco testemunho de

47 República, 357b-d.

48 República, 544d-545b e 580b-580c.

49 República 580c.

50 República 581c

51 Sobre a dificuldade ou a impossibilidade de efetivação da pólis paradigmática, fundada em palavras apenas e o consequente apelo a uma pólis interior, cfr. República, 592b, 591e; e 499b, 502c, 590e e segs. 
justiça. Também não somos amigos apenas das vantagens materiais advindas do nosso ofício, até porque se o nosso objetivo maior fosse ganhos e salários, teríamos optado por outras profissões. Mais uma vez, se não nos situamos no primeiro caso nem no terceiro, só podemos nos encontrar no segundo. Se não somos philósophos somos, por assim dizer, phílo-philósophos, pois ainda nos deixamos impressionar pelas honras, prestígios ou êxitos acadêmicos e, lamentavelmente, pelo espírito de competição que, não raro, decorre do desejo, mais ou menos consciente, de prevalecer sobre nossos pares. A nosso favor, poderíamos ainda alegar que não almejamos honras indevidas ou prestígios desmerecidos; damos a conhecer o nosso trabalho porque buscamos o diálogo inter-pares, a comunicação que visa, principalmente, ao reconhecimento do nosso esforço. Porém, no mínimo, temos de admitir o quanto é difícil delimitar a fronteira entre reconhecimento e prestígio, entre o desfrutar da justa glória ou da vanglória.

Parece-nos, então, que nesses dois esquemas triádicos sobre os gêneros dos bens e dos humanos equilibramo-nos no campo intermediário. Se já não esperamos qualquer irrupção de uma norma divina, podemos ao menos permanecer vigilantes para que sempre mais nos afastemos do terceiro plano e tentar, no que ainda nos for possível, nos aproximar do primeiro. Essa atenção ao pensamento por si mesmo não é um sonho vão. Na iminência de sua morte, Sócrates indica as pistas para esse percurso ao enfatizar que os filósofos não devem temer a pobreza material nem a desconsideração social dessa condição, como a maioria que se apega às riquezas, às honras, ao poder e à glória. Assim, o verdadeiro filósofo não pode viver como um philonikós sempre a procura de triunfar ${ }^{52}$.

Nestes nossos tempos em que o exercício da inteligência aliado ao cuidado primordial do ético raramente se impõe como um valor não flexível e não negociável, podemos nos lembrar do exemplo do matemático russo Grigory Perelman; tendo proposto a solução para a chamada conjectura de Poincaré, ele não se preocupou em divulgá-la em qualquer prestigiada publicação acadêmica, acessível apenas aos assinantes ou iniciados; lançou-a na agorá virtual para que todos pudessem ter acesso a seu trabalho. Em 2006, causou espanto nos meios intelectuais quando declinou receber do rei da Espanha a medalha Fields e a soma em dinheiro que lhe seria correspondente; sua justificativa para essa recusa, extraída de uma rara entrevista à revista The New Yorker, em 28 de agosto do mesmo ano, tem a limpidez de uma 
máxima socrática: "(O prêmio) é completamente irrelevante para mim. Qualquer pessoa entende que, se a demonstração estiver correta, não é necessário nenhum outro reconhecimento". Muito possivelmente, quanto mais estejamos próximos dessa pessoa qualquer menos nos distanciaremos dos valores inerentes à natureza do filósofo, tal como Platão a concebeu. Nessa direção, encontramos ainda ressonâncias nos testemunhos de alguns pensadores já muito distantes da antiguidade clássica, quando filosofia e vida eram inseparáveis; pensadores que também se distanciaram de honras sociais e acadêmicas: modernos como Spinoza e Rousseau, e contemporâneos como Simone Weil e Wittgenstein. Se optamos por pesquisar e lecionar na academia, ao menos não nos deixemos enredar em disputas por objetivos menores, nem cativar por quaisquer honrarias. 